\title{
Impacts of Certain Imposed Factors on Education and Educationists in Punjab, India
}

\author{
Navjot Kaur \\ Department of Political Science, Rimt University, Mandi Gobindgarh Punjab, India \\ * Corresponding author email: navjyotkaurbrar@gmail.com
}

Received: 03 March 2018 / Revised: 05 March 2018 / Accepted: 21 March 2018 / Published: 05 April 2018

\begin{abstract}
Quality achievements, teacher inputs and outputs require a universal level if our country have to compete with the developed nations. Firstly, this paper examines problems while implementing those according to the present conditions in the schools of Punjab and secondly how those problems affect educationists as employs and educationists as common man. Teacher can fulfil the desires of society if he himself is mentally free from hardships in social responsibilities and free from the threat of insecure future. Education is only way to achieve desired goals in life and to make people aware of their prospect and potentials. Due to disparities presented in the rural and urban conditions of schools of Punjab there are some issues presented which affects the education system but are ignored ever. Often ignored factors, policies and structures either by political will or by bureaucracy have many adverse effects on the thousands of educationists and their families throughout life. This paper thus depicts categories of Para teacher schemes including contractual and departmental, Unequal wages but equal desired output by department, same policies for rural and urban staff ignoring regional disparities, prioritization of subjects since Kothari commission(1964-1966) without considering demand of today's $21^{\text {st }}$ century globalised world, poor level of teacher trainings , misinterpretations of compulsory education, Annual confidential reports (ACR's) without feedback to employs, non-teaching works due to lack of support staff in schools which suffers teacher student contact timings and finally partial transfer policies in which some remained in urban areas forever and others remained in faraway places forever until and unless blessed by political will and ignoring goals of justice, liberty and equality and in last some remedies also suggested for the revision consideration. School education forms the foundation of an education system and this can be achieved only by providing the free environment.
\end{abstract}

Keywords: feedback, prioritisation, contractual, educationists.

\section{Introduction}

Although Punjab does well in the field of education relative to many states and South Asian countries as well specially in secondary education and youth literacy rates. Over the last decades many developing counties are trying large education reforms aims at rapidly expanding the education and to stand globally. With number of increasing educational NGO initiatives such as Pratham, Azim Premji, MV foundations and others are contributing in a number of dimensions, as well as in terms of their influence, advocacy voice/media profile, research capability and ability to mobilize funds for education both from individual donors in India and abroad and from the corporate sector (Kingdon, 2007). Government of Punjab clearly appreciates the need to ensure an adequate supply of professional teachers because only education is capable to cure all the social evils present in the society. Many public private partnerships experiments are done by governments, but educationists have to suffer from this type of experiments. Education should be priority on the development agenda but should not be based on experimentalism theory to save financial sources. Educationalists are not only teachers, but they are employees, people and part of social life also. They also have the social responsibilities and they are also prone to shouldering the burden of household activities 
Impacts of Certain Imposed Factors on Education and Educationists in Punjab, India

having number of family dependents because of greater societal expectations due to traditional values of our society (Singh \& Principal, 2012).

Unemployment rate in Punjab is still high and higher fee structures of private institutions are out of reach of people. Government is therefore responsible to provide better environment and better future. Although there have been several good efforts made by the governments to enhance the quality of education. Major public education initiatives have been taken by governments from time to time like Sarava Sikhsha Abhyan (SSA), Rashtriya Madbyamik. Shiksha Abhiyhan (RMSA), Mid-Day Meal (MDM), Computer Education(I.C.T.) and Para teacher Schemes etc. After providing qualified staff, free uniforms, free books, infrastructure for activitybased education, Edusat smart class rooms (EDUSAT E-LIBRARY) and Receive only terminals (ROT), I.C.T., Science, Math and Social science labs yet Public schools are lagging behind than private schools. However, despite progress in education levels there resides problem of teacher absenteeism, lack of staff, lack of infrastructure and financial resources in public school. Teacher absenteeism is not only physical but mental also which further signalling poor output. Mental absenteeism is due to imposed policies and agendas in form of contracts which are wasting time and energy of skilled staff in form of struggles against insecure future (Grewal, 2005). Bureaucratically or politically imposed factors which are neither suitable for educationists nor for students should be consider for revision and this is the need of the hour. As there are two broad levels of education i.e. school and higher. Hence this paper descriptively has sought to build a picture of school education in Punjab and to pick out the problems associated with the teachers as well.

\section{Prioritized Curriculum of Study}

General Period allotment in Punjab schools for subject priority from 6th to $10^{\text {th }}$ is shown in the Table 1. India's curriculum of secondary education has historically prioritized the study of Maths and Science than Arts and other subjects since Kothari Commission (1964-66) recommendations. According to this commission India's development needs were better met by Science and English than Historians (Lall \& House, 2005). This results the declining of interests in Arts field and students only study Arts as last resort. This commission was set up nearly 51 years before. Although priority of Maths and Science subjects was the need of that time to meet with conditions of $21^{\text {st }}$ century has also been effective however this require changes according to the present criteria of unemployment. Policy makers have to understand the requirements in present scenario of IT world so that we can control expectations of only seated government jobs in our young generation and we can also control brain drain from our country to developed countries. We are aware that maths, Science and English have its own place in education but there if we look towards the higher education there the scenario is opposite from schooling conditions. India's top business schools, Indian Institutes of technology (IITs), Indian institutes of management (IIMs) and universities are leading the world in technology and business fields (Lall \& House, 2005). There should also need to add the part time facilities for the students from $10^{\text {th }}$ onwards based on their field of study but this is the worst feature of our thinking that do not want to encourage the feeling of self dependency in our ward. This results in spending the whole life earning of parents.

Table 1: General Period allotment in Punjab schools shows subject priority from $6^{\text {th }}$ to $10^{\text {th }}$ (Session 2017-18).

\begin{tabular}{|l|l|l|l|l|}
\hline \multicolumn{1}{|c|}{ Subject } & Priority up to high classes & $\mathbf{9}^{\text {th }} \mathbf{- 1 0 ^ { \text { th } }} \mathbf{( 5 4 )}$ & Priority up to elementary & $\mathbf{6}^{\text {th }}-\mathbf{8}^{\text {th }} \mathbf{( 5 4 )}$ \\
\hline Maths & I & 8 & I & 9 \\
\hline Science & I & 8 & III & 7 \\
\hline English & II & 7 & II & 8 \\
\hline Social science & III & 6 & IV & 6 \\
\hline Hindi & IV & 5 & V & 5 \\
\hline Physical education & V & $4+2$ (SFP) & VI & $4+2(\mathrm{SFP})$ \\
\hline Additional subject & VI & 4 & VII & 4 \\
\hline Computer science & VII & 3 & VIII & 3 \\
\hline & & Total $=54$ & & Total $=54$ \\
\hline
\end{tabular}

Compiled from website Sources (“Department of School Education - Punjab (INDIA)," n.d.) 
Navjot Kaur, Adv. J Social Sci.; Vol. 2 Issue 1, pp: 32-39, May 2018

Hence no one even tried to revise that highly prioritised curriculum. There is need to analyse the interests of children rather than imposing the huge amount of subject burden on them because we also want Aristotle, Shakespeare, Plato, Freud, Bill Gates, Robert frost etc. Main adverse effect of subject priority is that children are so over burdened with subject matter that they are least interested in reading books of libraries, literature and remained away from our great heritage and culture. As National policy of education (NPE-1986) which was announced by Shri Rajiv Gandhi has stressed on Environment awareness, Science and technology education and yoga in schooling (Lall \& House, 2005) but if we compare the period allocation of the subjects in Punjab education policy we can see the results itself that IT field is lagging behind even than additional subjects which is contradictory with the higher education scenario.

\section{Compulsory Education Vs Right to Education Misinterpretations}

Main part of Indian education system is free and compulsory education for all children up to the age of 14. Indian Government has also banned child labour. However, this system is difficult to enforce due to economic disparity and social conditions. 93rd constitutional amendment bill making education a fundamental right has been passed now so as to make education right for education. Article 28 of the CRC (convention on the right of child) clearly states that a state party to the CRC shall make a primary education compulsory and available free for all. That means not only no school fee and/or uniform and transportation etc ("Children's Rights: Brazil | Law Library of Congress," 2009). The compulsion is for the parent and child meaning that if education is available then parents have to make sure that their child attends school and for the child that he/she has to go to school. The right to education is a universal right but up to now it is up to the parents to decide whether they send their child to school or not. Generally, it is believed in our country that 'compulsory' means only 'compulsion' on the state to make available facilities for education universally not 'compulsion' on the child or on parents. It is matter of discussion that many critics are unhappy with the imposed features of compulsory education ACT that "parents are bound to send their kids to school, failing which they can be prosecuted" but many associations have declared that parents should be punished for not sending their children ("Children's Rights: Brazil | Law Library of Congress," 2009). We have to consider children's opinion and teacher opinion. There is thus pressure on teacher throughout year belonged to elementary sections for full enrolment. Sometimes teachers are stressed as they have Pass that students who not even attended the school even a single day with the lowest grade. Hence there should be penalty for parents in small amount (Rupee one per day) as in Karnataka state. We can take example of Brazil in that country government is paying parents the equivalent of a minimum wages in order to enable them to send their children to school (“Children's Rights: Brazil | Law Library of Congress,” 2009).

Education is "public good" and hence the child has to undergo education whether or not he want it with what justification can one ask that the state provide all necessary finance for school infrastructure, rooms, faculty, toilets, drinking water, free mid-day meal, uniforms, free books, stipend and yet leave to parents to decide whether or not they wish to make use of these families. This is wastage is resources ("Children's Rights: Brazil | Law Library of Congress," 2009).

Consider about those parents who are more concerned with sustaining their immediate livelihood through farming labour which can also mean taking children out of school during harvest season to help in the fields. One provision to attract children which is taken from the school situated in G.p.s for girls Robjan district Rajanpur (Pakistan) is the distribution of edible oil by WEP (World Food Programme) to those children with regular attendance since they have no fixed day on which the edible oil is distributed (Voluntary Services Overseas, 2005). Education department should also encourage such donors from big firms and companies.

\section{Contractual Staff Problems}

Government should provide an enabling environment for teacher to do their job properly, policy makers need to pay closer attention to teacher management policies. Contractual staff are further demoralised because salaries are frequently disbursed late. No increment, no medical leave, only 3 months maternity 
leave, no medical reimbursement, no earned leave even though department want equal results or output from both categories. Department, governments and policy makers directly or indirectly harassing contractual staff by depriving them from every job benefit. They require at least $50 \%$ of each benefit while remaining on contractual period. There should be proper channel by Examination to go to department after completion of their contractual period. Policies of Government are much like that they have to retire on the same post, same salary, same wages and same status as when they joined. So there is need to analyse this factor of the recruitment of educationists on fixed terms, introduction of different terms and conditions for different categories of staff for the same post are so confusing and also increasing non-teaching work load in offices. A teacher with unsecure future in mind are serving in education department since 2005 and they are deprived off from so many benefits, still they are victims of partial policies of government.

There are various schemes of contractual staff like PICTES (regular but not under education department), SSA, RMSA, EGS, IEDC VOLUNTEERS and SERVICE PROVIDERS (VOLUNTEERS) in one school in education department. With the psychology of unsecure future, they are providing us the same results as department teachers. This is because of the limited job security of new contractual staff means they have a disincentive to work hard and as a result they are frequently absent mentally (not physically) as they try for alternatives employments or to struggle against department for equal work and equal job benefits. Hence there should be move by test to the department out of contractual staff according to their qualifications.

There are more complaints and problems like late receipts of salaries rather than salary levels. When salaries are regularly late teachers are understandably left frustrated, demoralised and in financial hardship and compelled for rallies against governments. This have a clear impact on teaching profession hence so many unions are evolving day by day and teachers are wasting their precious time on meetings and rallies. All these factors are detrimental to teacher performance. Teachers are also unhappy with the patron of equal work but different wages. When teacher voices regarding their future, wages, benefits are often excluded from policies by policy makers, responsible position bureaucrats, governments then this results into frustration of educationists, formation of unions and struggles (Voluntary Services Overseas, 2005). If problem of contractual staff remains then they will move towards private occupations like tuitions, coaching academies, small business to top up their salaries so as to meet the required amenities of life.

\section{$5 \quad$ Partial Transfer and Promotion Policies}

Teachers posted in rural, remote and insecure areas can emphasise more particular difficulties than posted in cities, local and urban areas. There is need to revise the policy for transfer because some started and ended his/her whole service locally and on the other hand one ended his/her whole service in rural area. No special incentives are offered to take up rural posts despite that these are often unattractive places of work. So this discrepancy of remaining on the same post in urban area for so many years closed the doors for the far away staff. There is need to interchange the staff after some interval of years between urban and rural schools so that everybody can get the benefit of being near to home so as to generalise this partial policy. There should also be a condition for couple to remain only one out of couple locally. Political influences on transfer policies can be avoided with this. Promotion policies in education department are only meant for the regular departmental employees. Contractual staff is deprived off from promotions. If they work under sponsored schemes they have to join and have to retire on the same post. Every person wants to go ahead in life. There is no promotion channel for staff outside the education department. If Government wants to keep them out of education department then the rules and policies should be so generalised with incentives, benefits and promotions. There should be 50-50 percent ratio of meritocratic (or seniority) and test for promotions rather than 100 percent seniority.

\section{Non-teaching Work Load on Educationists}

In the era of Information Technology educational department is just fighting with the problem of huge official work load. Due to lack of support staff (peon, clerk, gardeners and sweepers) teachers are forced to do official work (Voluntary Services Overseas, 2005). Official work is also increased with the various 
Navjot Kaur, Adv.J Social Sci.; Vol. 2 Issue 1, pp: 32-39, May 2018

schemes branches of various schemes like SSA BRANCH, RMSA BRANCH, PICTES BRANCH, GERNAL BRANCH, MID DAY MEAL BRANCH, E PUNJAB BRANCH and DSS BRANCH etc. If we check daily e mail routine from all these branches to schools and the burden of immediate required information from schools by offices plus daily student and teacher attendance to E-PUNJAB, websites related to DEO(District wise), PSEB registration, continuation, NATIONAL SCHOLARSHIPS PORTAL(NPS) and ASHIRWAD PORTAL for Post-Matric and Pre-Matric scholarships, SSA website, BLOCKS on district levels, complex schools and many more then we can analyse the burden of teacher specially of those teachers who made responsible for daily DAK by Principals. Teacher responsible for DAK cannot even enjoy a casual leave. In this way teachers are prevented from concentrating on their core activities because they all have to deal with administrative and clerical matters. Despite of this teachers have to perform many out of department works like SURVEY'S from time to time, ELECTION duties and to computerise data of many other departments. Although all information related to every school is available on E-PUNJAB website yet offices are always prefer to demand information each time from concerned schools and forward e-mails with the same scanned (as more time consumed on making Performa than putting information in pre-prepared Performa) Performa demanded by higher authorities with the immediate time bound condition which further lead to shuffle the environment of the school.

Every Secondary school in Punjab has a lot of paper consuming on Daily DAK. Although middle schools are attached with secondary school and having all information available in secondary schools including service books of employees and their complex secondary schools are responsible for sending DAK and information yet department is spending a huge amount of money for the internet connection bills of middle schools and deprive secondary schools from that amounts. Hence there is need to withdraw internet facility from middle schools because they have this facility in their concerned secondary schools. Government and utilise this amount to pay the internet bill for secondary schools. Teachers when assigned these tasks results in suffering of teacher student contact timing.

\section{$7 \quad$ Lack of Skilled Resource Persons in Teacher Trainings and Monitoring Teams}

Teachers want continuous professional developments through opportunities for training as we know institutions are the bridges between the people and government. Although teachers are providing playing a pivotal role in creating positive learning and achievements that will encourage children and their parents to value educations. Our governments of clearly appreciates the need to ensure an adequate supply of professional teachers after so many webs of tests like TET, CTET and subject tests etc. During recent education sector reforms, it introduced initiatives to train greater no of teachers that how they are responding to the newer. Hence there is need to analyse the teachers own attitude towards their profession and what their profession needs are? So, their training/seminars should be in higher educational institutes like universities, colleges etc. so that they can add the new research theories to their knowledge rather than taught by the same designation teachers as resource persons. Hence lack of resource persons during training are the biggest thrust. Even sometimes teachers are more educated and expert than resource persons. Resource persons are deputed from the same cadre without any test or special qualification on behalf of good terms with the higher officials of department.

Teachers are also not afraid of school inspections on the contrary they want more interaction with higher administration which is necessity so as to bridges communication flow from ground levels to higher authorities. Sometimes monitoring teams are uncooperative because they do not appreciate the value of education imparted by teachers by reaching in remote and areas. Instead of this they are criticised and noticed for being late without considering the situations to reach to those remote areas.

Hence monitoring teams should be based on seniority and test ratio so that they analyse teaching psychology of each educationists with their micro eyes. Sometimes monitoring team members tried to impose their teaching methods without understanding the student's way of learning. Every student has their own capability and has their own way of leaning and teacher who available for whole year to that class can better understand the psychology of student than monitoring team member who visited once a year. 


\section{Annual Performance Reports without Reviewing Feedback}

Annual confidential reports (ACR) (Annual confidential reports: chapter 8, n.d.) or self-appraisal reports are written with a view to adjudge performance and primary means of accessing employee's work, conduct, character and capabilities every year in the area. This system has two main objectives:

a. To improve performance of the subordinates in their performance job.

b. To access their potentials and prepare them for the jobs/field suitable to their personality (Annual confidential reports: chapter 8, n.d.).

Therefore, the columns of ACR's are filled up by the reporting, reviewing and accepting authorities with an objective and impartial manner. There should be correct overall assessment of work and conduct of employees or subordinates. Hence no one should be rewarded by flattering manner which are not based on actual facts. Education department demands ACR's every year from departmental, contractual and nonteaching staff as well but never gives back feedback or suggestions to educationists after signing by reviewing authority.

Hence teacher would favour a meritocratic system in which good performance is rewarded with promotions and appreciations. ACR's are only used to obtain increments, promotions by departmental regular staff and contractual employees (who are deprived from increments and promotions) are only to wait to use it in regular appointment file process. Hence reviewing authorities are not accessing teachers yearly on the basis of ACR's but they only depend up on monitoring teams to access performance of teachers. Adequate reviewing of ACR's with feedback can lessen certain checking and then further decrease the politicisation and reference culture in teaching.

\section{Less Efforts by School Management Committees}

Schools also want to see more than a token of efforts from school management committees in school matters. Teachers seek cooperation and interest of parents and community. Private school student's parents are so aware that they are equally participating with teachers but there is no positive outcome regarding this in rural government schools. Role of teachers as educators can be enhanced if support structure functions properly in addition to providing an enabling environment for teachers to do their job properly.

SMC could be a vehicle for promoting a partnership between the educators, parents, educated and respectable members of community. School can mobilise community to monitor teachers, students, infrastructures, problems of underage marriage of girls, female education and can encourage supporting efforts for schools. Similarly, SMC's can forward voices of educationists to local governments.

In most villages SMC's are according to the political will of that local area and often changed with changing political power. Hence there should be proper working duration instead in some unavoidable circumstances of SMC's so that they can work independently. Political appointments can be decreased in this way and financial spending can be fairly utilised for the institution. Hence this issue revealed a great deal of concern about the transparency of SMC's system.

\section{Suggestions}

Here are some remedies and some suggestions:

a. Teacher training programmes should be raised up to university levels so that they can enhance their capability according to new century.

b. Expected levels of resource persons and monitoring teams should be a preference so that they can impart their knowledge in a right way and by understanding different priorities for rural, remote and urban areas.

c. Teachers should encourage in reflecting their own style of teaching rather than imposing common methodology for intelligent as well as weak students. 
Navjot Kaur, Adv. J Social Sci.; Vol. 2 Issue 1, pp: 32-39, May 2018

d. We should have to understand the importance of each subject according to the interest of children with changing time rather than imposing our sticky rules which we have adopted before so many years.

e. Prioritisation should be analysed before applying because imposing and teaching have a great difference. There is need to revise the period allocation system of subject so as to put that subject to proper requisite standards.

f. Non-teaching work load can be decreased if official clerical staff try to fetch all information from EPUNJAB website and what required can be forwarded with ms excel, ms word Performa rather can scanned Performa.

g. Governments should try to apply only those policies which dealt with future and job security however contractual employees have equal commitment with respect to regular employees. Good and favouring Policies are requirement of not only students but also of educationists.

h. Involvement of SMC's, educationists, NGO's, Panchayats and parents counselling and adult education lectures are necessary to solve matters like drop out ratio, absent ratio, girls education to go ahead .

i. There is need to interchange the staff after some years of interval between urban and rural schools so as to generalise this transfer policy.

\section{Conclusions}

There is responsibility of the higher authorities in Education department to provide a stress-free environment for teaching. Despite the apparent lack of proper government support for school infrastructure there are several cases of teachers, SMC's and community making personal contributions for funding to schools. Fixed term or contractual educationists have had some unexpected consequences. The mechanism to determine wages of educationists may undermine reforms that aims to introduce competition and rewards for good performance. Educationists unions are struggling from many years for the constitutional goals of equal work, equal pay, justice and equality for all categories. As rules are for the wellness of humanity and rules only exists to make life easier. So, policy makers have to keep in mind the positive and negative impacts of those factors. Those factors can have impacts on educationists when we consider them as employees and people in the form of insecure future and on the education in the form of burden without outcome. Experiments on education are worst thing. Teachers need to be regarded as equal partners in education planning so as to decrease the loss of better students to private schools.

Hence, we need to analyse that why the same difficulties still exist from nearly sixty years. When voices against policies are ignored then this results in the failure of policies. So, there is need to provide attractive environment and workplace for the teachers as well as educationists. But in spite of these challenges it is remarkable to see that teacher are showing their commitment towards their profession for the wellness of generations. To achieve the desired goal of universalisation of education, this requires not only qualification, proper infrastructure, deep subject proficiency of teachers, government and NGO initiatives but it also requires good working conditions for teachers full of mental piece and especially with secure future.

\section{How to Cite this Article:}

Kaur, N. (2018, April 5). Impacts of Certain Imposed Factors on Education and Educationists in Punjab, India. Advanced Journal of Social Science, 2(1), 32-39. https://doi.org/10.21467/ajss.2.1.32-39

\section{References}

Annual confidential reports: chapter 8. (n.d.). Retrieved from www.cidap.gov.in/files/download/crimemanual/_CHAPTER-08.doc

Children's Rights: Brazil | Law Library of Congress. (2009). Retrieved April 5, 2018, from https://www.loc.gov/law/help/childrights/brazil.php

Department of School Education - Punjab (INDIA). (n.d.). Retrieved April 5, 2018, from http://www.ssapunjab.org/

Grewal, T. K. (2005). JOB SATISFACTION AMONGST THE TEACHERS OF UN AIDED PUBLIC SCHOOLS. CHAPTER - IV. Shodhganga. Retrieved from http://shodhganga.inflibnet.ac.in/handle/10603/23697

Kingdon, G. G. (2007). The Progress of School Education in India (ESRC Research Group). Retrieved from 
Impacts of Certain Imposed Factors on Education and Educationists in Punjab, India

http://www.gprg.org/pubs/workingpapers/pdfs/gprg-wps-071.pdf

Lall, M., \& House, C. (2005). The Challenges for India's Education System. Retrieved from http://marielall.com/wp/wpcontent/uploads/Chatham-house-indiaeducation.pdf

Singh, B., \& Principal, J. (2012). Teacher Education: Issues and their Remedies. International Journal of Educational Planning \& Administration, 2(2), 2249-3093. Retrieved from http://www.ripublication.com/ijepa.htm

Voluntary Services Overseas. (2005). TEACHER PROFESSIONALISM IN PUNJAB: RAISING TEACHERS' VOICES FINAL DRAFT. Retrieved from https://www.vsointernational.org/sites/default/files/teacher-professionalism-in-punjab-pakistan_tcm76-22701.pdf

Publish your research article in AIJR journals-

$\checkmark$ Online Submission and Tracking

$\checkmark$ Peer-Reviewed

$\checkmark$ Rapid decision

$\checkmark$ Immediate Publication after acceptance

$\checkmark \quad$ Articles freely available online

$\checkmark \quad$ Retain full copyright of your article.

Submit your article at journals.aijr.in
Publish your books with AIJR publisher-

$\checkmark$ Publish with ISBN and DOI.

$\checkmark$ Publish Thesis/Dissertation as Monograph.

$\checkmark$ Publish Book Monograph.

$\checkmark$ Publish Edited Volume/ Book.

$\checkmark$ Publish Conference Proceedings

$\checkmark \quad$ Retain full copyright of your books.

Submit your manuscript at books.aijr.org 